\title{
Glaciological investigations in the balance year 1983-84
}

\section{OLAV LIESTØL}

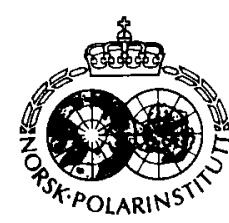

Liestøl, O. 1986: Glaciological investigations in the balance year 1983-84. Polar Research 4 n.s., 97-101. In mainland Norway, mass balance measurements were carried out on the Hardangerjøkulen and Storbreen glaciers. Both had a small negative net balance. The two glaciers measured in Svalbard, Brøggerbreen and Lovénbreen, also had negative balances as in the previous 19 years. Length fluctuations measured at eight glacier tongues indicate that one was advancing, one in equilibrium, and six were retreating.

Olav Liestøl, Norsk Polarinstitutt, P.O. Box 158, 1330 Oslo Lufthavn, Norway.

\section{Storbreen}

The winter accumulation measured in the middle of May was $170 \mathrm{~g} / \mathrm{cm}^{2}$. This is c. $120 \%$ of the last 35 years' average. The summer temperature was above the mean, which resulted in an ablation of $200 \mathrm{~g} / \mathrm{cm}^{2}$. The result was a net balance of $-30 \pm 10 \mathrm{~g} / \mathrm{cm}^{2}$, which is near to the mean, $-27 \mathrm{~g} / \mathrm{cm}^{2}$.

Air photographs of the glacier were taken in the last part of August. A map will be constructed when new control points have been fixed.

\section{Hardangerjøkulen}

Conditions on Hardangerjøkulen were almost the same as on Storbreen, but with higher mass bal- ance figures. The winter balance was 205 , the summer balance 215 , and the net balance $-10 \pm 20 \mathrm{~g} / \mathrm{cm}^{2}$. The large uncertainty in the measurements is caused by the loss of most of the stakes during the winter.

Length fluctuations of eight glaciers were measured and the results are presented in Table 1.

Table 1. Length fluctuations of some glacier tongues.

\begin{tabular}{lclc}
\hline Jotunheimen: & & Jostedalsbreen: \\
Styggedalsbreen & $-2 \mathrm{~m}$ & Austerdalsbreen & $-14 \mathrm{~m}$ \\
Leirbreen & $-10 \mathrm{~m}$ & Briksdalsbreen & $-11 \mathrm{~m}$ \\
& & Fåbergstølbreen & $-15 \mathrm{~m}$ \\
& & Stegholtbreen & $-11 \mathrm{~m}$ \\
Svartisen: & & Nigardsbreen & 0 \\
Engabreen & $+4 \mathrm{~m}$ & & \\
\hline
\end{tabular}

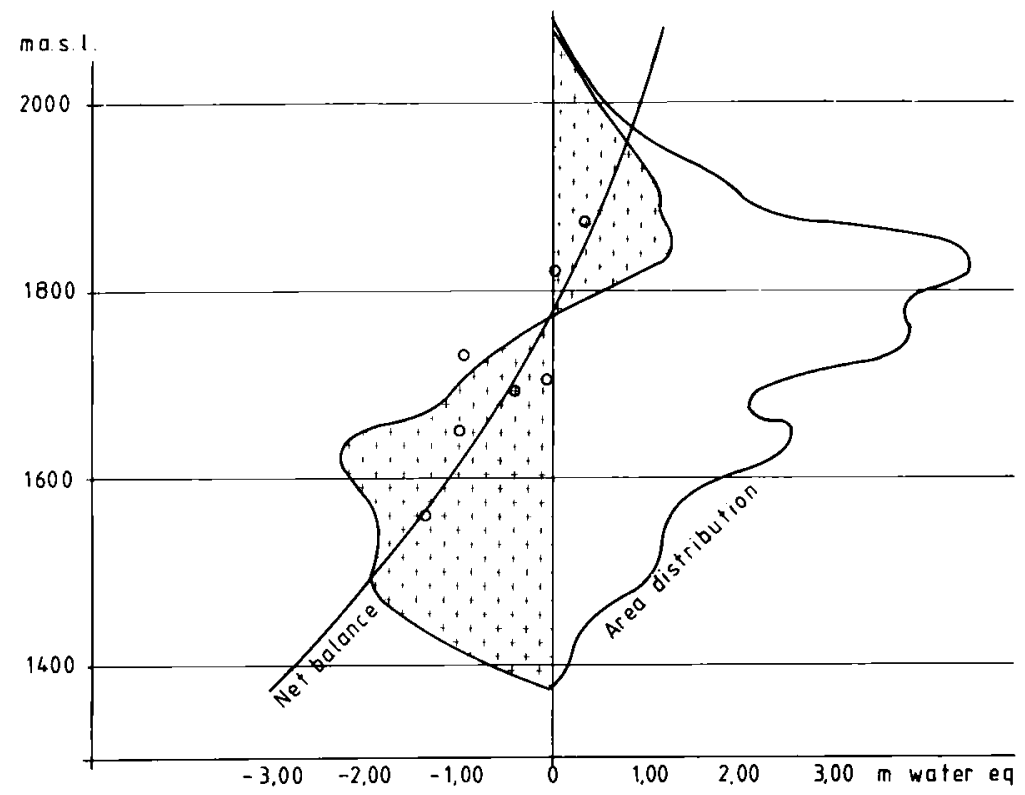

Fig. 1. Net mass balance variation on Storbreen 1983-84 in relation to height above sea level. 


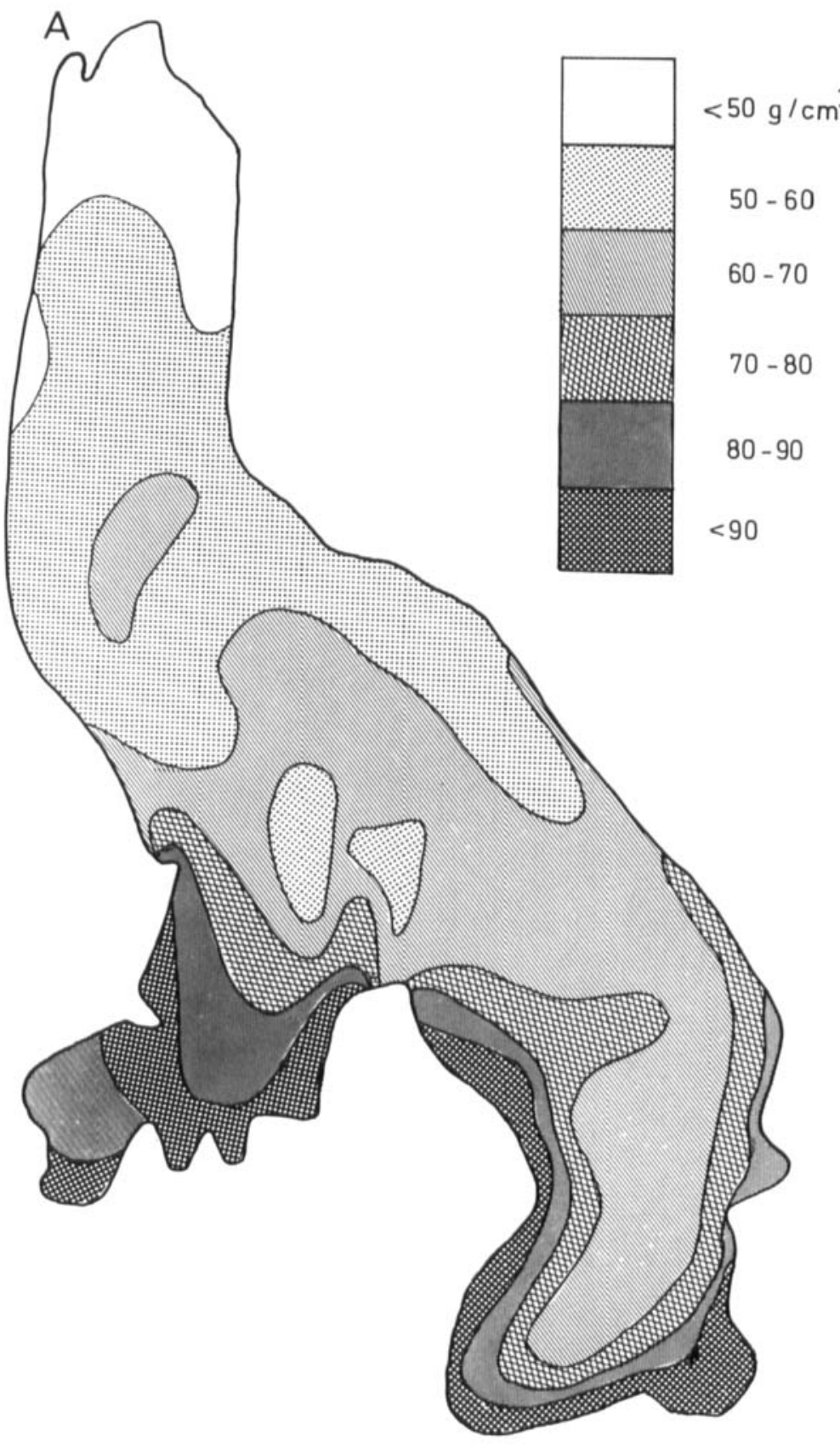

Fig. 2. Snow distribution at the end of May 1984 on A. Austre Brøggerbreen and $B$. Midre Lovénbreen. The location of the ablation stakes is indicated by circles. Note that the stakes on Brøggerbreen have a location at the centre line of the glacier where the snow depth is not representative of the height interval. This problem will also affect the net ablation measured on the stakes which is seen in the diagram in Fig. 3. The real balance is therefore calculated by using the accumulation soundings and measurements of the remaining winter snow at different heights. 


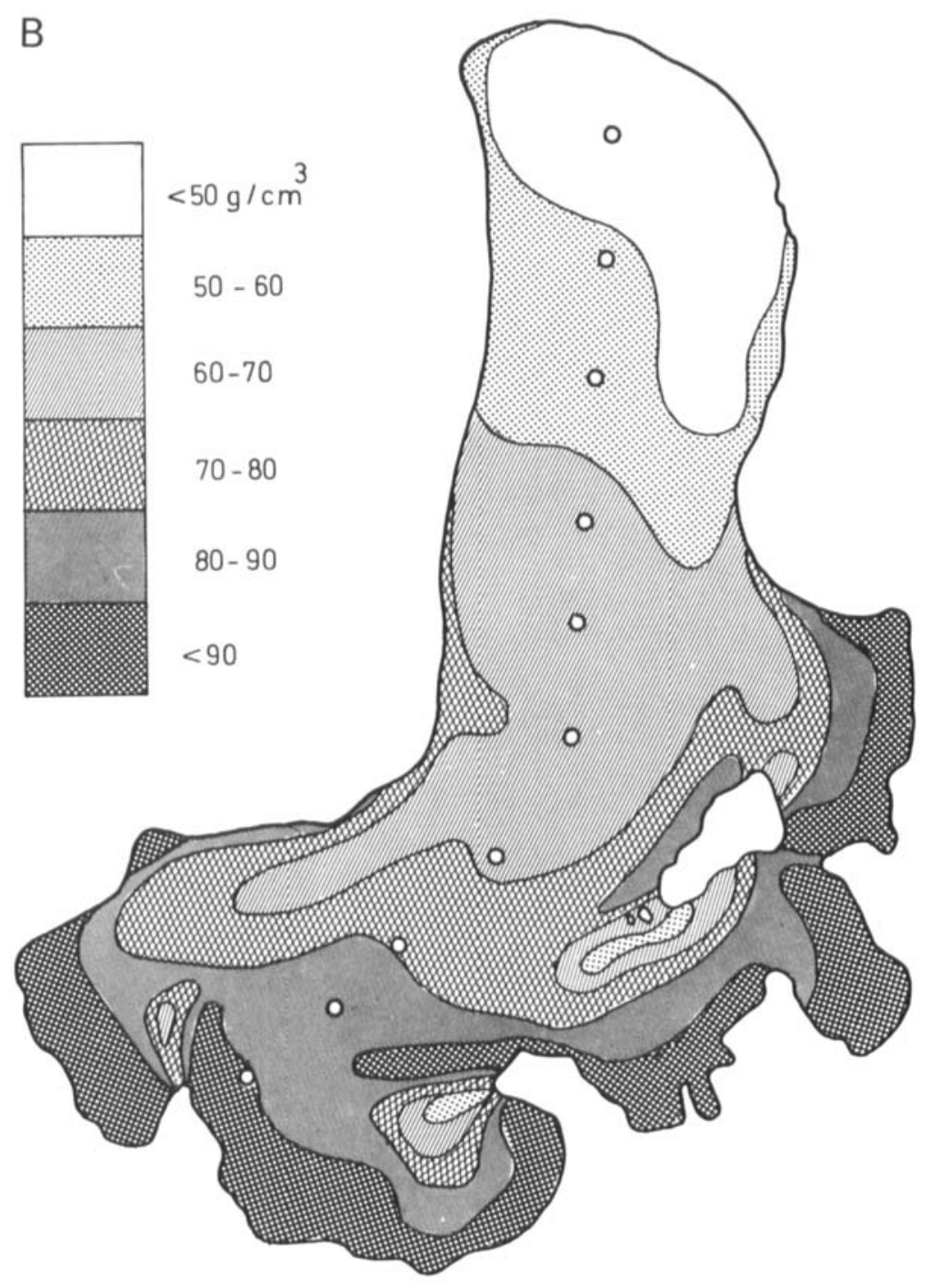

Fig. 2. Continued. 
100

O. Liestøl

Bröggerbreen 1983-1984

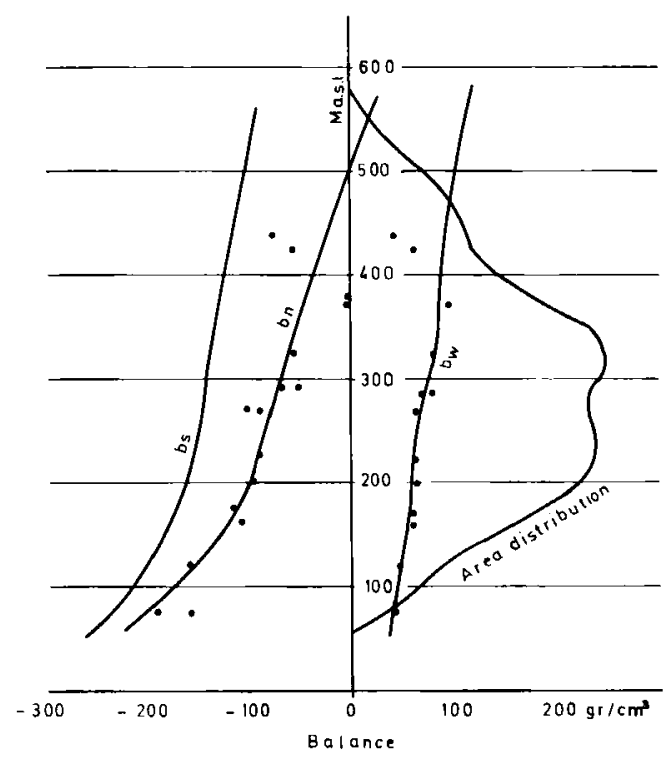

Lovénbreen 1983-1984

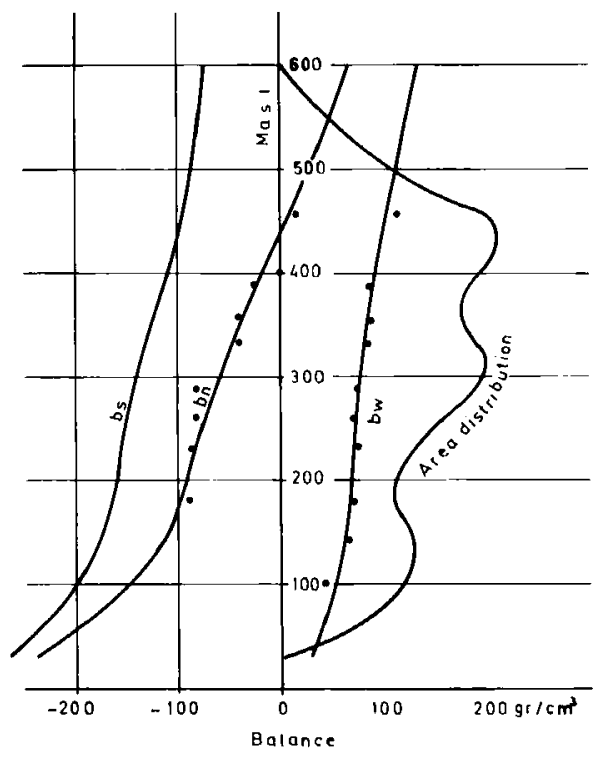

Fig. 3. Mass balance variations in relation to height in 1983-84 of Austre Brøggerbreen and Midre Lovénbreen.

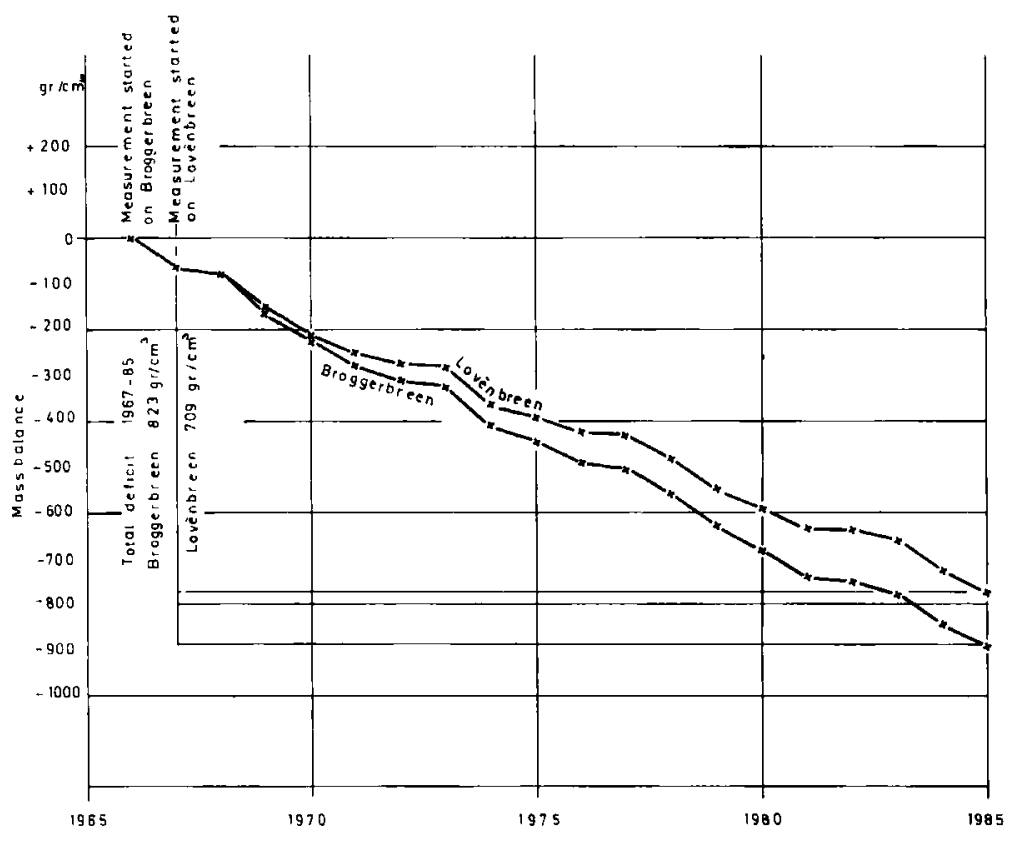

Fig. 4. Cumulative net balance of the Brøgger and Lovén glaciers. 


\section{Glaciers in Svalbard}

As in the previous 17 years, mass balance measurements were carried out on two glaciers, Brøggerbreen and Lovénbreen, near Ny-Ålesund in Svalbard. Stake readings, snow depth, and density measurements started in the last week of May. A short period with mild weather and rain in the middle of the winter caused a hard ice crust in the snow on the lower part of the glaciers. This layer was difficult to penetrate and made snow soundings very laborious.

With a height interval of $50 \mathrm{~m}$ the superimposed ice was measured by core drilling. This ice layer was remarkably thin in the spring of 1984 , only $5 \mathrm{~cm}$ at the lowest stakes, and totally missing upwards from c. $200 \mathrm{~m}$ a.s.l. The calculated superimposed ice formed during the melt season, however, was of normal thickness.

The ablation was measured at the stakes in the middle of September and also checked in the spring of 1985 before melting started that year.

The results are given in Table 2, together with the figures from the previous 17 years.

Fig. 4 shows graphically the development of the mass balance of the two glaciers. Since 1966 Brøggerbreen has lost $823 \mathrm{~g} / \mathrm{cm}^{2}$ averaged over the total area of the glacier, corresponding to a lowering of the surface of $9.15 \mathrm{~m}$. This is more than $10 \%$ of the total glacier volume. The fact that Brøggerbreen every year has a larger deficit than Lovénbreen is probably because the first glacier has a lower average height above sea level than the second.

Table 2. Mass balance figures in $\mathrm{g} / \mathrm{cm}^{2}$ for Austre Brøggerbreen and Midre Lovénbreen, 1967-1983.

\begin{tabular}{lcrrrrr}
\hline & \multicolumn{3}{c}{ Austre Brøggerbreen } & \multicolumn{3}{c}{ Midre Lovénbreen } \\
Year & $\overline{\mathrm{c}}$ & $\overline{\mathrm{a}}$ & $\overline{\mathrm{b}}$ & $\overline{\mathrm{c}}$ & $\overline{\mathrm{a}}$ & $\overline{\mathrm{b}}$ \\
\hline $1966-67$ & 77 & 142 & -65 & & & \\
$1967-68$ & 57 & 67 & -10 & 48 & 51 & -3 \\
$1968-69$ & 57 & 133 & -93 & 41 & 125 & -84 \\
$1969-70$ & 37 & 91 & -54 & 36 & 89 & -53 \\
$1970-71$ & 65 & 123 & -58 & 70 & 116 & -46 \\
$1971-72$ & 95 & 126 & -31 & 98 & 120 & -22 \\
$1972-73$ & 74 & 82 & -8 & 82 & 84 & -2 \\
$1973-74$ & 75 & 167 & -92 & 70 & 159 & -89 \\
$1974-75$ & 78 & 109 & -31 & 83 & 104 & -21 \\
$1975-76$ & 72 & 117 & -45 & 75 & 110 & -35 \\
$1976-77$ & 76 & 87 & -11 & 80 & 84 & -4 \\
$1977-78$ & 75 & 131 & -56 & 81 & 129 & -48 \\
$1978-79$ & 77 & 148 & -71 & 80 & 146 & -66 \\
$1979-80$ & 75 & 127 & -52 & 83 & 126 & -43 \\
$1980-81$ & 46 & 101 & -55 & 51 & 97 & -46 \\
$1981-82$ & 64 & 68 & -4 & 66 & 64 & 2 \\
$1982-83$ & 70 & 97 & 142 & -73 & 74 & 142 \\
$1967-84$ & 68 & 114 & -46 & 70 & 107 & -37 \\
\hline
\end{tabular}

